\title{
Determining the Attitudes of Undergraduate Students Having Vocational Music Education towards Individual Instrument Course According to Different Variables
}

\author{
Taner Uluçay
}

Department of Fine Arts Education, Faculty of Education, Erzincan University, Turkey

Copyright $(2017$ by authors, all rights reserved. Authors agree that this article remains permanently open access under the terms of the Creative Commons Attribution License 4.0 International License

\begin{abstract}
This study was carried out in order to determine attitudes of undergraduate students who studied music vocationally towards the individual instrument course according to the variables of grade, gender, individual instrument and graduated high school type. The research data were obtained from 102 undergraduate students studying in Erzincan University, Faculty of Education, Fine Arts Education Department, Music Program. The research data were provided using "Individual Instrument Attitude Scale" developed by Yalçınkaya and Eldemir. [1] The data collected using the scale were analyzed with SPSS 22 package software, and were tabulated. In the light of the data presented in the tables, the data were interpreted. At the end of the research, it was noticed that there was no significant difference between individual instrument course attitude scores of the students according to the level of grade; number of female students was more than the number of male students, and there was a significant difference between individual instrument course attitude scores according to gender. Although the number of participants was limited, it was concluded that individual instrument course scores of male students was more than the attitude scores of female students (LA: 59.23>45.97). It was also determined that there was a significant difference between the individual instrument course attitude scores according to the type of instrument, and the lowest score was noticed to be for violin instrument with the most number of students (LA: 41.97). In general, line average scores of Turkish music instruments were determined to be higher rather than the universal instrument scores. In the research, consequently, individual instrument course attitude scores were analyzed according to the type of graduated high school, and line averages of the pre-service music teachers graduated from fine arts high schools were noticed to be higher rather than the pre-service music teachers graduated from other high schools, and this difference was concluded to be significant (LA: $52.35>48.00)$.
\end{abstract}

Keywords Vocational Music Education, Individual
Instrument Course, Individual Instrument Course Attitude Scale, Attitude

\section{Introduction}

Besides being an artistic process, and music education is an educational process that is efficient upon personality development of individuals and that includes scientific information. Students can have the abilities of cooperating, socializing, expressing themselves to others and developing self-confidence through music education.

The field of music education and occupation of music teaching was considered as a craft in the beginning; they turned into art subsequently; and from then on they were qualified as both art and science. At the present time, it has tended to be turned into a distinctive musical behavior engineering being considered as a whole with all its artistic, scientific and technological dimensions. [2]

Collaboration strategies' being included into music education as a teaching model can affect achievement levels of the students, and this will gain meaning through maintaining this process in a well-planned way. [3]

One of the sub-types of music education as an individual and social phenomenon is "vocational music training" including music trainer educating process. "Instrument training" dimension included within the scope of vocational music education process is the cornerstone and indispensable fundamental factor of the process.

"Vocational music education" is for talented people who choose, want to choose, tend to choose, have the possible to choose or seem to choose a job related to the whole or a branch of music, and aims to provide individuals acquire musical behaviors and knowledge branch, job or profession requires. [2]

There are some variables affecting the success level of the students during instrument training process of pre-service 
music teachers. Students' loving the instrument they play, attitude and approaches of course's lecturers, and study habits of the students, etc. can be listed among these variables.

Playing an instrument is hard and complicated. A good teacher who teaches playing the instrument, a talented student ready to and keen on learning, and a well-organized teaching program are all remarkable. [4]

The instrument pre-service music teacher will be trained should be on a type pre-service teacher will accompany to educational music repertoire and sing and play polyphonic songs. An accompaniment instrument is needed to fulfill this. The most appropriate instrument is piano, organ or guitar. [5]

Attitude is defined as "manner, course" in Turkish Language Association Dictionary. [6] According to Ülgen, attitude is a phenomenon acquired through learning, shaping the behaviors of individuals and causing bias during the decision-making process. If the attitude we develop towards an object or event is positive, there is the possibility for our decisions to be positive; on the other hand, if the attitude we develop for an object or event is negative, then our decision is possible to be negative. [7]

Attitudes of pre-service music teachers towards the individual instrument course have an efficient role upon their loving, embracing and being keen on playing their individual instruments. When individual instrument course is considered as both process and result-based interaction process, attitudes of students towards individual instrument course is regarded to be investigated in terms of different variables.

\section{Problem Sentence}

What is the attitude level of the pre-service music teachers studying at Erzincan University Music Teaching Department towards individual instrument course?

\subsection{Sub-Problems}

1. Is there a significant difference between attitudes of students towards individual instrument course according to their level of grade?

2. Is there a significant difference between attitudes of students towards individual instrument course according to their gender?

3. Is there a significant difference between attitudes of students towards individual instrument course according to the instrument they play?

4. Is there a significant difference between attitudes of students towards individual instrument course according to the type of graduated high school?

\section{Purpose}

The purpose of this research was to reveal the attitudes of students having vocational music education towards individual instrument course considering different variables.

\section{Method}

\subsection{Research Model}

In this study, it was aimed to determine the attitudes of undergraduate students having vocational music training towards individual instrument course, and relation screening model was used in reference to this aim.

\subsection{Study Group}

The study group of the research included 102 undergraduate students studying at Erzincan University, Music Department. The research data were obtained through the implementation of the data collection tools by the author. Frequency and percentage distributions related to grade, gender, instrument and graduated high school type of the students were presented in tables.

Table 1. Frequency and Percentage Distributions According to the Grades of Students

\begin{tabular}{|c|c|c|}
\hline Grade & f & $\%$ \\
\hline 1 & 27 & 26,5 \\
\hline 2 & 19 & 18,6 \\
\hline 3 & 27 & 26,5 \\
\hline 4 & 29 & 28,4 \\
\hline Total & 102 & 100,0 \\
\hline
\end{tabular}

Table 2. Frequency and Percentage Distributions According to Gender

\begin{tabular}{|c|c|c|}
\hline Gender & $\mathrm{f}$ & $\%$ \\
\hline Woman & 41 & 40,2 \\
\hline Man & 61 & 59,8 \\
\hline Total & 102 & 100,0 \\
\hline
\end{tabular}

Table 3. Frequency and Percentage Distributions According to Instruments

\begin{tabular}{|c|c|c|}
\hline Instrument & $\mathrm{f}$ & $\%$ \\
\hline Violin & 38 & 37,3 \\
\hline Viola & 12 & 11,8 \\
\hline Guitar & 11 & 10,8 \\
\hline Cello & 14 & 13,7 \\
\hline Flute & 12 & 11,8 \\
\hline Oud & 8 & 7,8 \\
\hline Baglama & 3 & 2,9 \\
\hline Contrabass & 2 & 2,0 \\
\hline Tambour & 1 & 1,0 \\
\hline Qanun & 1 & 1,0 \\
\hline Total & 102 & 100,0 \\
\hline
\end{tabular}


Table 4. Frequency and Percentage Distributions According to the Type of Graduated High School

\begin{tabular}{|c|c|c|}
\hline Type of Graduated High School & $\mathrm{f}$ & $\%$ \\
\hline Fine Arts High School & 82 & 80,4 \\
\hline Other High Schools & 20 & 19,6 \\
\hline Total & 102 & 100,0 \\
\hline
\end{tabular}

\section{Data Collection Tools}

\subsection{Instrument Course Attitude Scale}

In the study, "Individual Instrument Course Attitude Scale" developed by Yalçınkaya and Eldemir [1] was used as the data collection tool. The scale included 18 items, and was on five-point Likert type. Varimax rotation principal components analysis method and factor analysis were performed in order to determine the construct validity of the scale; Cronbach alpha reliability coefficient of the scale was calculated as 947. Kaiser-Meyer Olkin (KMO) value of the scale was found as ,96, and Barlett Test value was determined as 4081. [8]

In order to determine to what extent the scale used in the study and the research subject fit with each other, factor analysis was performed to the scale items in the light of the data obtained from students; and because the items in the scale had no value below 30 , scale items were used as they were. Cronbach Alpha coefficient of the scale was found as 0,822 , and the reliability coefficient was determined as .88 .

\subsection{Analysis of Data}

The statistics related to the research variables were tested at $p>.05$ level of significance using SPSS 22.00 statistical software. "Individual Instrument Course Attitude Scale" scores were added, and scale score level was created. These scores were correlated with the personal data related to the students, and attitude levels of the students towards the individual instrument course were determined. In order to determine whether the data had a normal distribution or not, Shapiro-Wilk Test was performed.At the end of the test, the data were specified not to have a normal distribution. In order to find answer to the sub-problems of the study, Kruskal-Wallis as one of the non-parametric tests was used, and Mann-Whitney U-Test was performed in order to find individual instrument attitude scores of according to gender and graduated high school.

Shapiro-Wilk is a non-parametric statistic test. Shapiro-Wilk test was compared with other normality tests, and strength of this test was suggested to be better rather than the others. [9]

Kruskal-Wallis test was used to test the significance of the difference observed between the scores of the groups related to a variable in one-factor experimental studies between the groups including limited number of experimental subjects. This process was suggested when normality assumption of one-way ANOVA as a parametric test was not met. The research question could be asked from the type of difference or relationship. Mann Whitney U-Test tested whether the scores obtained from two unrelated samples differed significantly from each other or not. [10]

\section{Findings and Interpretation}

\subsection{The Findings Related to the Sub-problem of "Is there a significant difference between attitudes of students towards individual instrument course according to their grade?"}

Kruskal-Wallis test was performed in order to analyze the individual instrument attitude scores of pre-service music teachers according to the level of grade, and the results were presented in Table 5 .

Table 5. Kruskal-Wallis Test Results According to the Grade Level Variable of Individual Instrument Course Attitude Scale Total Scores

\begin{tabular}{|c|c|c|c|}
\hline & Level of Grade & N & Line Average \\
\hline \multirow{4}{*}{ Attitude-average } & $1^{\text {st }}$ Grade & 27 & 51,39 \\
\cline { 2 - 4 } & $2^{\text {nd }}$ Grade & 19 & 55,24 \\
\hline & $3^{\text {rd }}$ Grade & 27 & 55,06 \\
\hline & $4^{\text {th }}$ Grade & 29 & 45,84 \\
\hline & Total & 102 & \\
\hline Chi-square & 1,756 & & \\
\hline SD & 3 & & \\
\hline$p$ & 0,624 & & \\
\hline
\end{tabular}

When Table 5 was analyzed,chi-square value related to the individual instrument course attitude scores according to the level of grade was found to be 1,756 , there was a difference between the level of grades, but this difference was noticed to be insignificant (p: $0.624>0.5$ ). when attitude scale line averages were analyzed, it was noticed in the Table that the highest score was at the second grade (LA: 55.25), and the lowest score was at the fourth grade (LA: 45.84).

\subsection{The Findings Related to the Sub-problem of "Is there a significant difference between the attitudes of students towards individual instrument course according to their gender?"}

Mann-Whitney U-Test was performed in order to analyze individual instrument attitude scores of pre-service music teachers according to their gender, and the results were presented in Table 6 .

When Table 6 was analyzed, number of female students was noticed to be higher rather than the number of male students(N: 61>41). When line averages were investigated, individual instrument attitude scores of the female students were determined to be higher rather than the scores of male students although number of male students was higher (LA: $59.73>45.97)$. Another finding possible to be seen in the 
Table was the significance of the difference between female and male students (p: $0.2<0.5$ ).

Table 6. Mann-Whitney U-Test Results According to the Gender Variable of Individual Instrument Course Attitude Scale Total Scores

\begin{tabular}{|c|c|c|c|}
\hline & Gender & N & Line Average \\
\hline \multirow{3}{*}{ Attitude-average } & Male & 41 & 59,73 \\
\cline { 2 - 4 } & Female & 61 & 45,97 \\
\cline { 2 - 4 } & Total & 102 & \\
\hline $\begin{array}{c}\text { Mann-Whitney } \\
\text { U-Test }\end{array}$ & 913,000 & & \\
\hline $\mathrm{Z}$ & $-2,3$ & & \\
\hline $\mathrm{p}$ & 0,2 & & \\
\hline
\end{tabular}

6.3. The Findings Related to the Sub-problem of "Is there a significant difference between the attitudes of students towards individual instrument course according to the instrument they play?"

Kruskal-Wallis test was performed in order to analyze the individual instrument attitude scores of pre-service music teachers according to the instrument they played, and the results were presented in Table 7 .

Table 7. Kruskal-Wallis Test Results According to the Instrument Type of Individual Instrument Course Attitude Scale Total Scores

\begin{tabular}{|c|c|c|c|}
\hline \multirow{4}{*}{ Attitude-average } & Instrument & $\mathrm{N}$ & Line Average \\
\hline & Violin & 38 & 41,97 \\
\cline { 2 - 4 } & Viola & 12 & 47,58 \\
\cline { 2 - 4 } & Guitar & 11 & 54,73 \\
\cline { 2 - 4 } & Cello & 14 & 53,36 \\
\cline { 2 - 4 } & Flute & 12 & 52,21 \\
\cline { 2 - 4 } & Lute & 8 & 69,81 \\
\cline { 2 - 4 } & Baglama & 3 & 94,33 \\
\cline { 2 - 4 } & Contrabass & 2 & 46,50 \\
\cline { 2 - 4 } & Tambour & 1 & 102,00 \\
\cline { 2 - 4 } & Qanun & 1 & 75,00 \\
\cline { 2 - 4 } & Total & 102 & \\
\hline Chi-square & 17,332 & & \\
\hline SD & 9 & & \\
\hline p & 0,44 & & \\
\hline
\end{tabular}

When Table 7 was analyzed, it was noticed that there was a significant difference between the individual instrument course attitude scores according to the type of instrument students played (p: $0.44<0.5)$. When the Table was investigated, line average related to violin instrument was noticed to have the lowest value (LA: 41.97). In order to find which groups provided the significant difference noticed in test findings, Mann-Whitney U-Test was performed, and the results were presented in Table 8 .
Table 8. Mann-Whitney U-Test Results Related to the Groups with Significant Difference According to Individual Instrument Course Attitude Scale Scores

\begin{tabular}{|c|c|c|c|}
\hline Instrument & $\mathrm{N}$ & Line Average & Sig. \\
\hline \multirow{2}{*}{$\begin{array}{l}\text { Guitar } \\
\text { Violin }\end{array}$} & 11 & 31,18 & \multirow{3}{*}{0,15} \\
\hline & 38 & 23,21 & \\
\hline Total & 49 & & \\
\hline \multirow{2}{*}{$\begin{array}{c}\text { Violin } \\
\text { Baglama }\end{array}$} & 38 & 19,66 & \\
\hline & 3 & 38,00 & \\
\hline \multicolumn{4}{|l|}{ Total } \\
\hline \multirow{2}{*}{$\begin{array}{l}\text { Cello } \\
\text { Violin }\end{array}$} & 14 & 31,50 & \multirow{3}{*}{0,14} \\
\hline & 38 & 24,66 & \\
\hline Total & 52 & & \\
\hline \multirow{2}{*}{$\begin{array}{l}\text { Flute } \\
\text { Violin }\end{array}$} & 12 & 29,54 & \multirow{3}{*}{0,2} \\
\hline & 38 & 24,22 & \\
\hline Total & 50 & & \\
\hline \multirow{2}{*}{$\begin{array}{l}\text { Violin } \\
\text { Lute }\end{array}$} & 38 & 21,49 & \multirow{2}{*}{0,25} \\
\hline & 8 & 33,06 & \\
\hline Total & & 46 & \\
\hline
\end{tabular}

When Table 8 was investigated, the highest values among the line averages related to the groups with significant difference were noticed to be expressed in bold characters.

\subsection{The Findings Related to the Sub-problem of "Is there a significant difference between the attitudes of students towards individual instrument course according to the type of school they graduated?"}

Mann-Whitney U-Test was performed in order to analyze individual instrument attitude scores of pre-service music teachers according to the type of graduated high school, and the results were presented in Table 9 .

Table 9. Kruskal-Wallis Test Results According to the Variable of High School Type of Individual Instrument Course Attitude Scale Total Scores

\begin{tabular}{|c|c|c|c|}
\hline & Type of High School & N & $\begin{array}{c}\text { Line } \\
\text { Average }\end{array}$ \\
\hline \multirow{3}{*}{ Attitude-average } & Fine Arts High School & 82 & 52,35 \\
\cline { 2 - 4 } & Other High Schools & 20 & 48,00 \\
\hline & Total & 102 & \\
\hline $\begin{array}{c}\text { Mann-Whitney } \\
\text { U-Test }\end{array}$ & 750,000 & & \\
\hline $\mathrm{Z}$ &,- 591 & & \\
\hline $\mathrm{p}$ &, 555 & & \\
\hline
\end{tabular}

When Table 9 was analyzed, line average scores of fine arts high school was noticed to be higher rather than the scores of other high schools $(52.35>48.00)$, but this difference did not create a significance ( $p: 0.55>0.5)$. 


\section{Discussion}

According to the research results, the students who showed the most interest upon individual instrument course studied at the $2^{\text {nd }}$ grade, and the ones who showed the least interest were determined to study at the $4^{\text {th }}$ grade.

In the study, male students were concluded to be more interested in individual instrument course rather than the female students.

In the research, the students playing violin were noticed to show less interest towards individual instrument course rather than the other students; attitude levels of the students playing guitar and flute as universal instruments were concluded to be high. Furthermore, attitudes of the students playing "baglama, tambour, qanun and lute" towards the individual instrument course were determined to be higher rather than the attitudes of students playing universal instruments.

Attitudes of the students graduated from fine arts high schools towards the individual instrument course were noticed to be higher rather than the students graduated from other high schools.

\section{Suggestions}

1. Different approaches and methods can be used in individual instrument courses held in different grades. Alternative lecturing techniques considering the psychological moods of the students can also be used in order to provide them to attend the courses more willingly.

2. Within the bounds of the possibility, instruments pre-service teachers will play fondly should be preferred in their selection of instrument. Beside the universal instruments, each student should be provided with the opportunity of having the education of Turkish Music instruments upon their request.

3. If a student is unsuccessful at individual instrument course, reasons of these should be investigated, and solutions should be searched for a successful process and result interviewing with the student. The subjects such as the communication with the lecturer of the course, playing the instrument fondly, and feeling satisfaction with the instrument, etc. should be discussed, and an efficient individual instrument course process should be created.

4. While determining the individual instrument, physical, psychological and sociological properties of the students should be considered. Students should be interviewed one by one, and the most appropriate individual instrument should be chosen by the help of a questionnaire or inventory.
5. Information on music experience of students should be obtained, and instrument selection should be made considering the musical background. The factors such as graduated high school type, and special music trainings taken previously should be regarded. Individual instruments that will be actively used during teaching life and that is appropriate to the age should be selected and taught to the students who have not played an instrument before.

\section{REFERENCES}

[1] YALÇINKAYA, B., ELDEMİR, A. (2013). Bireysel Çalg1 Dersine İlişkin Tutum Ölçeğinin Geliştirilmesi. Mustafa Kemal Üniversitesi, Sosyal Bilimler Enstitüsü Dergisi, Cilt: 10 Sayı 21, s. 29-36.

[2] UÇAN, A., (2005). Müzik Eğitimi, Temel Kavramlar-İlkeler-Yaklaşımlar ve Türkiye'deki Durum. Evrensel Müzikevi. ANKARA

[3] ULUDAĞ, A. K. (2015). Okul çalgıları (gitar) eğitimi dersinde ekip çalışmasına dayalı stratejiler ve öğrenci başarı düzeylerine etkisi. Hacettepe Üniversitesi Eğitim Fakültesi Dergisi [Hacettepe University Journal of Education], 30(3), 147-159.

[4] ÇILLDEN, Ş., Çalg1 Eğitiminde Nitelik Sorunu, Cumhuriyetimizin 80. Yılında Müzik Ĕ̈itimi Sempozyumu Bildiri Kitabı. İnönü üniversitesi Eğitim Fakültesi Güzel Sanatlar Eğitimi Bölümü Müzik Öğretmenliği Programı, s. 297-303, MALATYA

[5] SAĞER, T., (2003), Müzik Öğretmeninin Çalgısı ve Mesleksel Yaşama Etkisi, Cumhuriyetimizin 80. Yılında Müzik Eğitimi Sempozyumu Bildiri Kitabı. İnönü üniversitesi Eğitim Fakültesi Güzel Sanatlar Eğitimi Bölümü Müzik Öğretmenliği Program1, s. 357-363, MALATYA

[6] Online available from http://www.tdk.gov.tr/index.php?option=comgts\&kelime= TUTUM

[7] AYAYDIN, A., KURTULDU, M.K., (2010), Güzel Sanatlar Eğitimi Bölümü Öğrencilerinin Bilimsel Araştırma Yöntemleri Dersine İlișkin Tutumları, Abant İzet Baysal Üniversitesi Dergisi, Cilt:10, Sayı:2 BOLU

[8] YALÇINKAYA, B., ELDEMIR, A., SÖNMEZÖZ, F., (2014). Müzik Öğretmeni Adaylarının Bireysel Çalgı Dersine Yönelik Tutumlarının Değerlendirilmesi. Turkish Studies-International Periodical for The Languages. Literature and History of Turkish or Turkic Volume 9/2 Winter 2014, p. 1583-1595. ANKARA TURKEY

[9] SHAPIRO,S.S., WILK,M.B., ve CHEN,H.J. (1968). "A comparative study of various tests of normality".Journal of the American Statistical Association, C.63 say.1343-1372.

[10] BÜYÜKÖZTÜRK, Ş., (2008), Sosyal Bilimler İçin Veri Analizi El Kitab1, (9. Bask1), Pegem Akademi Yayınlarl, Ankara, (1. Bask1 2002). 